\title{
Physiological alterations and production of guava under water salinity and nitrogen fertilizer application
}

\section{Alterações fisiológicas e produção de goiabeira sob salinidade da água e adubação nitrogenada}

\author{
Idelfonso Leandro Bezerra $^{1 *}$; Hans Raj Gheyi ${ }^{2}$; Reginaldo Gomes Nobre ${ }^{3}$; Joicy \\ Lima Barbosa ${ }^{4}$; Reynaldo Teodoro de Fátima ${ }^{5}$; Jutahy Jorge Elias ${ }^{6}$; Leandro de \\ Pádua Souza ${ }^{7}$; Felipe Luenio de Azevedo ${ }^{8}$
}

\begin{abstract}
Adequate management of saline water irrigation and nitrogen $(\mathrm{N})$ fertilizer application in agriculture can contribute substantially to expanding guava cultivation in the semi-arid region of Northeast Brazil. This study aimed to evaluate gas exchange and production of 'Paluma' guava cultivated with different levels of water salinity and $\mathrm{N}$. The experiment was carried out in drainage lysimeters under field conditions in an experimental area of the Federal University of Campina Grande (UFCG), Campus of Pombal, PB, Brazil. The experimental design was randomized blocks, in a $5 \times 4$ factorial scheme, with five levels of water salinity - ECw $\left(0.3,1.1,1.9,2.7\right.$ and $\left.3.5 \mathrm{dS} \mathrm{m}^{-1}\right)$ and four doses of $\mathrm{N}(70,100,130$ and $160 \%$ of the recommendation) with three replicates. The dose relative to $100 \%$ corresponded to 541.1 $\mathrm{mg}$ of $\mathrm{N} \mathrm{dm}^{-3}$ of soil. The following production components were evaluated: number of fruits, mean fruit weight, polar and equatorial diameter of fruits, and polar diameter/equatorial diameter ratio. In addition, the following physiological variables were evaluated at 180 days after fruit pruning: stomatal conductance, $\mathrm{CO}_{2}$ assimilation rate, internal $\mathrm{CO}_{2}$ concentration and transpiration rate. $\mathrm{CO}_{2}$ assimilation and transpiration rate were used to calculate instantaneous water use efficiency. The interaction between water salinity and $\mathrm{N}$ doses did not cause significant effects on any variable studied. Irrigation water salinity above $0.3 \mathrm{dS} \mathrm{m}^{-1}$ hampered gas exchange at 180 days after fruit pruning and negatively affected production components.
\end{abstract}

Key words: Psidium guajava. Physiology. Saline water. Nitrogen.

1 Prof., Departamento de Agronomia. Fundação Universidade Federal de Rondônia, UNIR, Rolim de Moura, RO, Brasil. E-mail: idelfonsobezerra@gmail.com

2 Prof. Visitante, Universidade Federal do Recôncavo da Bahia, UFRB, Cruz das Almas, BA, Brasil. E-mail: hans@pq.cnpq.br

3 Prof., Departamento de Ciências e Tecnologia, Universidade Federal Rural do Semi-Árido, UFERSA, Caraúbas, RN, Brasil. E-mail: rgomesnobre@yahoo.com.br

4 Discente, Curso de Graduação em Agronomia, UFCG, Pombal, PB, Brasil. E-mail: joicy.barbosa0@gmail.com

5 Discente, Curso de Pós-Graduação em Agronomia, Universidade Federal da Paraíba, UFPB, Centro de Ciências Agrárias, Areia, PB, Brasil. E-mail: reynaldo.t16@gmail.com

6 Discente, Curso de Pós-Graduação em Ciências Agrárias, UEPB, Centro de Ciências Biológicas e da Saúde, Campina Grande, PB, Brasil. E-mail: jutahy.jorge33@gmail.com

7 Discente, Curso de Pós-Graduação em Engenharia Agrícola, UFCG, Centro de Tecnologia e Recursos Naturais Campina Grande, PB, Brasil. E-mail: engenheiropadua@hotmail.com

8 Discente, Curso de Pós-Graduação em Zootecnia, UFCG, Centro de Saúde e Tecnologia Rural, Patos, PB, Brasil. E-mail: felipe. luenio19@gmail.com

* Author for correspondence 


\section{Resumo}

As práticas adequadas de manejo da irrigação com água salina e adubação nitrogenada na agricultura pode contribuir de forma expressiva para a expansão do cultivo da goiabeira na região semiárida do nordeste brasileiro. Objetivou-se com este trabalho avaliar as trocas gasosas e a produção da goiabeira 'Paluma' cultivada sob diferentes níveis de salinidade da água e doses de nitrogênio. O experimento foi conduzido em lisímetros de drenagem sob condições de campo em área experimental da Universidade Federal de Campina Grande (UFCG), Campus de Pombal, PB. O delineamento experimental foi em blocos casualizados, em esquema fatorial 5 x 4, com cinco níveis de salinidade de água - CEa $(0,3,1,1,1,9,2,7$ e 3,5 dS m$\left.~^{-1}\right)$ e quatro doses de nitrogênio (70, 100, 130 e 160\% de recomendação) com três repetições; sendo a dose referente a $100 \%$ correspondeu a $541,1 \mathrm{mg} \mathrm{de} \mathrm{N} \mathrm{dm}^{-3} \mathrm{de}$ solo. Foram avaliados os seguintes componentes de produção: número de frutos, massa média de frutos, diâmetro polar e equatorial de frutos e relação diâmetro polar/equatorial de frutos. Avaliaram-se ainda as seguintes variáveis fisiológicas aos 180 dias após a poda de frutificação: condutância estomática, taxa de assimilação de $\mathrm{CO}_{2}$, concentração interna de $\mathrm{CO}_{2}$ e taxa de transpiração. Com os valores de taxa de assimilação de $\mathrm{CO}_{2}$ e taxa de transpiração foi determinada a eficiência instantânea no uso da água. A interação entre a salinidade das águas e as doses de nitrogênio não promoveu efeitos significativos em nenhuma variável estudada. $\mathrm{O}$ aumento da salinidade da água de irrigação acima de $0,3 \mathrm{dS} \mathrm{m}^{-1}$ comprometeu as trocas gasosas aos 180 dias após a poda de frutificação e os componentes de produção.

Palavras-chave: Psidium guajava. Fisiologia. Água salina. Nitrogênio.

\section{Introduction}

Fruit species have great importance in Brazil, especially guava which reached a production level of 359.3 thousand tons in 2014 in a cultivated area of 16 thousand hectares. The states of São Paulo (37.2\%) and Pernambuco (27\%) are the largest national producers of guava (IBGE, 2014). This fruit crop is one of the most cultivated on commercial scale in most regions of Brazil (PEREIRA et al., 2011).

Guava has great importance among the fruit crops cultivated and commercially exploited in irrigated areas of Northeast Brazil, but these areas are characterized by high evaporation rates, irregular rainfall and inadequate drainage. In addition, the water from the sources frequently has electrical conductivity above $1.5 \mathrm{dS} \mathrm{m}^{-1}$, which can limit agricultural production, causing morphological, physiological and biochemical alterations in plants, hampering fruit development, production and quality (NEVES et al., 2009; DIAS et al., 2011; FREIRE et al., 2014). The effects of high levels of salt in the soil is manifested by changes in physical and chemical attributes, which reduce the osmotic potential of the soil solution, and by the direct action of specific ions on the mineral nutrition of plants (CAVALCANTE et al., 2009; DIAS et al., 2011).

Among various processes affected by salinity, it is known that water absorption by plants and gas exchange are negatively affected because saline stress causes morphological alterations, such as nutritional imbalance, reductions in stomatal conductance, photosynthetic rate and transpiration, and it can probably occur in response to stomatal closure, regulated by hormones, due to alterations in photochemical parameters and in carbon metabolism (CHAVES et al., 2009); this stress leads to reduction in the osmotic potential. It is assumed that this behavior can reduce plant growth because of the lower absorption of $\mathrm{CO}_{2}$ from the atmosphere and, consequently, causes a reduction in photosynthesis (PRAXEDES et al., 2010).

Various studies have been carried out to evaluate the effects of saline water irrigation on the guava crop (CAVALCANTE et al., 2005; MACIEL et al., 2007; SOUZA et al., 2016, 2017). However, these have been limited to rootstock production only. Therefore, it is important to conduct studies 
to identify the effects of saline stress on the guava crop in the post-grafting stage.

In this context, adopting management strategies to mitigate the deleterious effects of salinity on plants is of great importance for the establishment of crops in the semi-arid region of Northeast Brazil. Management of $\mathrm{N}$ fertilizer application stands out among these practices. According to Barhoumi et al. (2010), application of $\mathrm{N}$ fertilizer, besides promoting plant growth, can also reduce the effect of salinity on plants. Such an effect can be attributed to the functions of the $\mathrm{N}$ in plants, since it performs structural functions, participating in various organic compounds which are vital for the plant, such as amino acids, proteins and proline. In addition, studies conducted by Lacerda et al. (2003) and Silva et al. (2008) have demonstrated that the accumulation of these organic solutes increases the plants' capacity for osmotic adjustment to salinity and increases crop resistance to water and saline stress. Thus, adequate management of nitrogen fertilizer application can be an alternative to mitigate the effects of irrigation water salinity on guava plants.

Given the above, this study aimed to evaluate the effect of water salinity levels and different $\mathrm{N}$ doses on the physiological variables and production components of guava during the first production cycle.

\section{Material and Methods}

The experiment was carried out from October 2015 to July 2017 at the Center of Sciences and AgriFood Technology (CCTA) of the Federal University of Campina Grande (UFCG), Pombal-PB, Brazil $\left(6^{\circ} 48^{\prime} 16^{\prime \prime} \mathrm{S} ; 37^{\circ} 49^{\prime} 15^{\prime \prime} \mathrm{W} ; 144 \mathrm{~m}\right)$, in pots adapted as lysimeters under field conditions. According to Köppen's classification, the region is classified as hot and semi-arid (BSh), with a mean annual temperature of $28{ }^{\circ} \mathrm{C}$ and rainfall of approximately $750 \mathrm{~mm}$ year-1. Monthly values for mean rainfall, maximum and minimum temperatures and relative humidity in the municipality throughout the study period are presented in Figure 1.

Figure 1. Data on climatic components recorded during the experiment from October 2015 to July 2017 at an automatic station located close to the municipality of Pombal. INMET (2017).

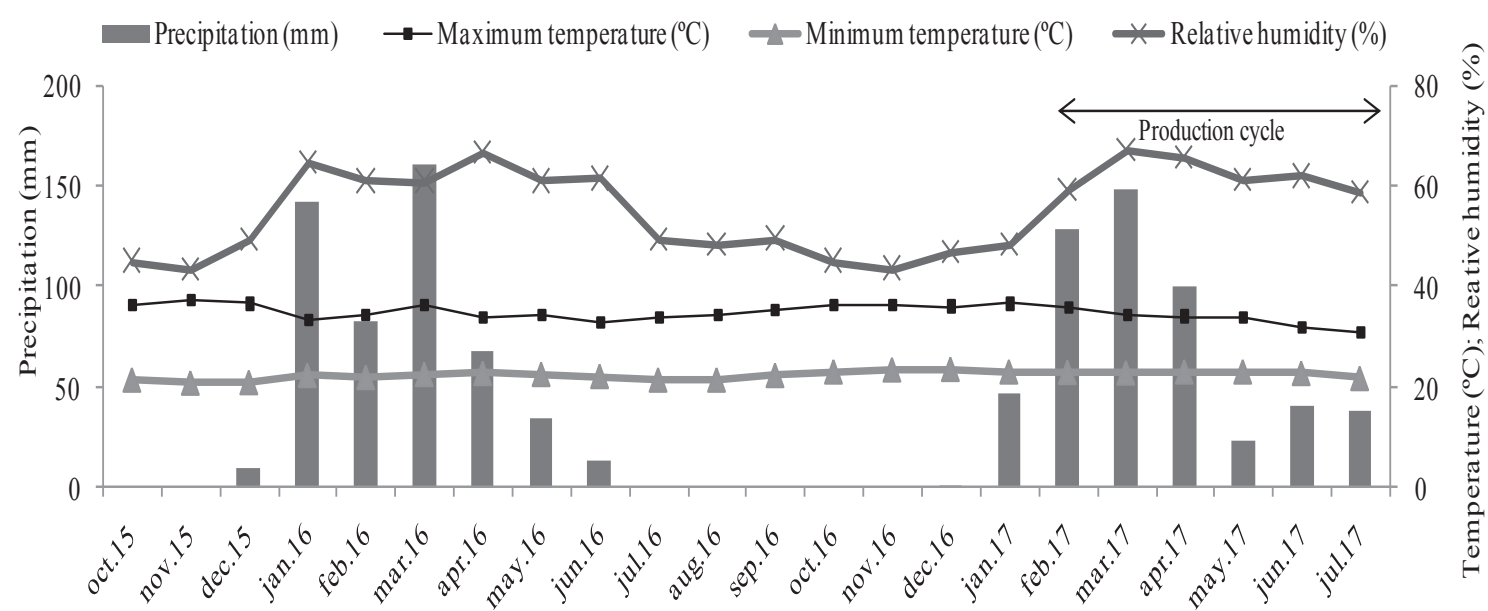


The experimental design was randomized blocks, in a $5 \times 4$ factorial scheme, with three replicates. Treatments corresponded to five levels of irrigation water salinity (ECw levels of $0.3,1.1,1.9$, 2.7 and $3.5 \mathrm{dS} \mathrm{m}^{-1}$ ) and four $\mathrm{N}$ doses $378.7,541.1$, 703.4 and $865.7 \mathrm{mg}^{-1} \mathrm{~N} \mathrm{dm}^{-3}$ of soil, corresponding to $70,100,130$ and $160 \%$ of the recommendation for greenhouse experiments, respectively (SILVA, 2015). Plots consisted of 100-L plastic pots adapted as lysimeters, containing one plant each.

$\mathrm{ECw}$ levels were obtained by dissolving $\mathrm{NaCl}$ in water taken from the local supply system $(\mathrm{ECw}=0.3$ $\mathrm{dS} \mathrm{m}^{-1}$ ). The amount of $\mathrm{NaCl}$ was determined based on the empirical equation proposed by Rhoades et al. (2000): $\mathrm{Cs}=10 \times(\mathrm{ECwd}-\mathrm{ECw}) \times \mathrm{Eqw}$, in which $\mathrm{Cs}=$ salt concentration $\left(\mathrm{mg} \mathrm{L}^{-1}\right)$; ECwd and $\mathrm{ECw}=$ desired level of water electrical conductivity and electrical conductivity of the local supply water $\left(\mathrm{dS} \mathrm{m}{ }^{-1}\right)$, respectively; and Eqw $=$ equivalent weight of the salt, in this case 58.45 .

The soil used in the experiment was classified as Fluvic Neosol (EMBRAPA, 2013). Samples of this soil were collected and then analyzed at the Laboratory of Soils and Plant Nutrition of the UFCG, Campus of Pombal. The chemical and physical characteristics of the soil, determined according to Donagema et al. (2011), are presented in Table 1.

Table 1. Chemical and physical characteristics of the soil used to cultivate the guava cv. 'Paluma'.

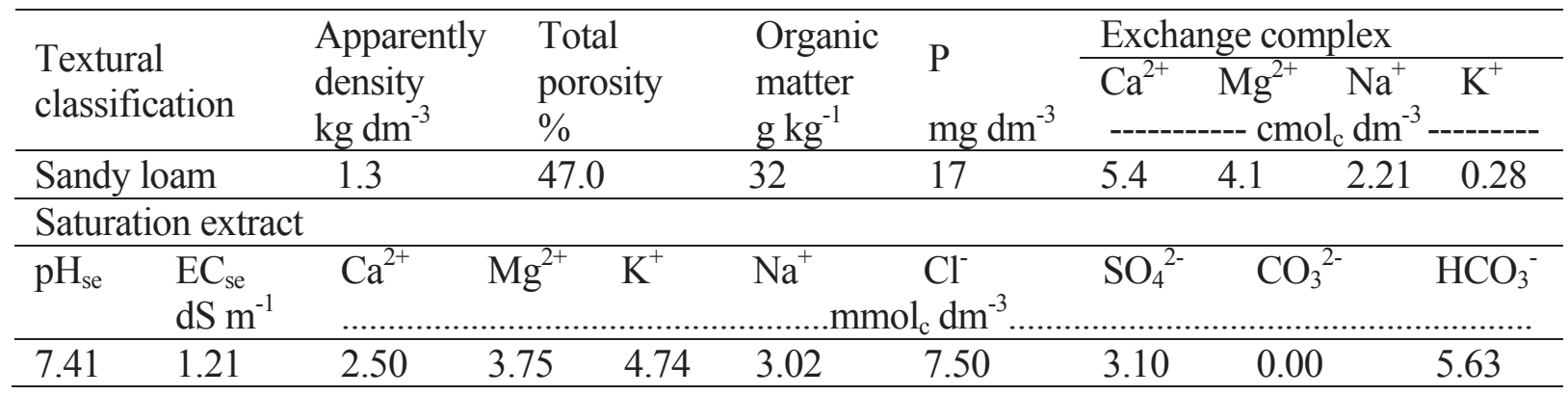

$\mathrm{pH}_{\mathrm{se}}-\mathrm{pH}$ of the soil saturation extract; $\mathrm{EC}_{\mathrm{se}}-$ electrical conductivity of the soil saturation extract at $25^{\circ} \mathrm{C}$; organic matter was determined by Walkley-Black wet digestion; $\mathrm{Ca}^{2+}$ and $\mathrm{Mg}^{2+}$ were extracted with $1 \mathrm{~mol} \mathrm{~L}^{-1} \mathrm{KCl}$ at $\mathrm{pH} 7.0$; $\mathrm{Na}^{+}$and $\mathrm{K}^{+}$were extracted with $1 \mathrm{~mol} \mathrm{~L}^{-1} \mathrm{NH}_{4} \mathrm{OAc}$ at $\mathrm{pH}$ 7.0; P was extracted with Mehlich 1.

The rootstocks were originally from 'Crioula' guava seeds from a commercial plantation at the Mocó Agropecuário Farm, municipality of Aparecida, PB. Grafting was performed at 180 days after sowing, $5 \mathrm{~cm}$ above the rootstock collar. The cultivar 'Paluma' was used as scion, being a vigorous genotype with easy propagation and good tolerance to pests and diseases, especially rust (Puccinia psidii Wint.) (MANICA et at., 2001). In addition, it is readily available and the most cultivated cultivar in Brazil, although poorly evaluated in terms of tolerance to salinity in interaction with $\mathrm{N}$ doses (DIAS et al., 2012).
In October 2015, when the grafted seedlings of 'Paluma' guava had four pairs of true leaves, they were transplanted to 150 -L lysimeters perforated at the bottom to allow free drainage. The lysimeters were filled using $150 \mathrm{~kg}$ of substrate composed of Fluvic Neosol + sand, at a proportion of $85 \%$ and $15 \%$, respectively. After placed in the lysimeters, the material was brought to field capacity using water with $\mathrm{ECw}$ of $0.3 \mathrm{dS} \mathrm{m}^{-1}$.

Fertilizer was manually applied using $189.5 \mathrm{~g}$ of single superphosphate (as a single dose at planting) and $17.28 \mathrm{~g}$ of potassium chloride split into three parts; $1 / 3$ of the recommended potassium chloride 
dose was applied at planting and the other two $1 / 3$ were applied at 30 and 60 days, respectively, after transplanting.

Treatments began at 15 days after transplanting (DAT) and irrigation using salinized water was performed, according to the treatment, based on plant water demand, determined by the difference between the volume applied and drained in the previous irrigation. This was estimated by drainage lysimetry, maintaining soil moisture close to field capacity. Irrigation was applied twice a day, in the early morning and late afternoon, except in periods of rain. At 40 DAT, the water volume applied through irrigation was adjusted to provide a leaching fraction of 0.15 as a management practice to avoid excessive accumulation of salt in the soil.

Treatment with $\mathrm{N}$ fertilizer through fertigation began at 25 DAT. The doses were split into 28 weekly applications. One fifth of the dose was applied in the first eight weeks because the root system occupied only a small volume in the lysimeter. The remainder of the $\mathrm{N}$ was equally applied over 20 weeks. The $\mathrm{N}$ source was urea $(45 \% \mathrm{~N})$, which was dissolved in 0.3 $\mathrm{dS} \mathrm{m}^{-1}$ water and used in all treatments.

Mechanical weeding, training and spraying were necessary to prevent and control fruit flies (Anastrepha spp. and Ceratitis capitata), bugs (Monalonion annulipes, Leptoglossus gonagra, L. stigma, L. zonatus, L. fasciatus, Holhymenia clavigera) and guava psyllids (Trizoida limbata).

At 60 DAT, branches were selected with respect to size, vigor and health, and pruning was performed to standardize the plants, leaving three main branches per plant which were responsible for forming the base of the crown, as recommended by EMBRAPA (2010). In February 2017, plants were subjected to continuous fruit pruning; only mature branches capable of flowering were pruned, leaving $15 \mathrm{~cm}$ in length on average.
Production was evaluated based on the number of fruits per plant and mean fruit weight. The first production cycle began at 30 days after fruit pruning. In the period of fruit maturity, the following parameters were measured: fruit polar diameter (FPD) and fruit equatorial diameter (FED).

During production, the following leaf gas exchange parameters were measured 180 days after fruit pruning (DAFP): internal $\mathrm{CO}_{2}$ concentration $\mathrm{Ci}\left(\mu \mathrm{mol} \mathrm{m} \mathrm{m}^{-2} \mathrm{~s}^{-1}\right)$; stomatal conductance - $g s$ (mol of $\left.\mathrm{H}_{2} \mathrm{O} \mathrm{m}^{-2} \mathrm{~s}^{-1}\right)$; transpiration rate $-E\left(\mathrm{mmol}\right.$ of $\mathrm{H}_{2} \mathrm{O} \mathrm{m}^{-2}$ $\left.\mathrm{s}^{-1}\right)$ and $\mathrm{CO}_{2}$ assimilation rate $-A\left(\mu \mathrm{mol}\right.$ of $\mathrm{CO}_{2} \mathrm{~m}^{-2}$ $\left.\mathrm{s}^{-1}\right)$. Measurements were conducted using a portable infrared gas analyzer (IRGA) (model LCPro + , ADC BioScientific Ltd.). $\mathrm{CO}_{2}$ assimilation rate $(A)$ and transpiration rate $(E)$ values were used to calculate the instantaneous water use efficiency - WUEi (A/E) $\left(\left[\left(\mu \mathrm{mol} \mathrm{m} \mathrm{m}^{-2} \mathrm{~s}^{-1}\right)\left(\mathrm{mmol} \text { of } \mathrm{H}_{2} \mathrm{O} \mathrm{m}^{-2} \mathrm{~s}^{-1}\right)^{-1}\right]\right.$. All measurements of gas exchange were performed in fully expanded mature leaves (third leaf from the apex). Readings were taken between 08:00 and 10:00 $\mathrm{h}$, using an artificial source of radiation with an intensity of $1200 \mu \mathrm{mol} \mathrm{m} \mathrm{m}^{-2} \mathrm{~s}^{-1}$, at ambient temperature and $\mathrm{CO}_{2}$ concentration (BRITO et al., 2012).

The data obtained were subjected to analysis of variance using the F-test at 0.05 probability level and, in cases of significance, polynomial regression analysis was carried out using the program SISVAR (FERREIRA, 2011).

\section{Results and Discussion}

Irrigation water salinity had a significant effect on the variables stomatal conductance (gs), $\mathrm{CO}_{2}$ assimilation rate $(A)$, internal $\mathrm{CO}_{2}$ concentration $(C i)$, transpiration rate $(E)$ and instantaneous water use efficiency (WUEi) (Table 2). In contrast, N fertilizer application and the interaction between irrigation water salinity and $\mathrm{N}$ dose $(\mathrm{S} \times \mathrm{ND}) \mathrm{did}$ not affect any of the variables studied. 
Table 2. Summary of the analysis of variance for stomatal conductance $(g s), \mathrm{CO}_{2}$ assimilation rate $(A)$, internal $\mathrm{CO}_{2}$ concentration $(C i)$, transpiration rate $(E)$ and instantaneous water use efficiency (WUEi) in guava cv. 'Paluma' with saline water irrigation and different nitrogen doses at 180 days after fruit pruning.

\begin{tabular}{lcccccc}
\hline \multirow{2}{*}{ Source of variation } & \multirow{2}{*}{ DF } & \multicolumn{5}{c}{ Mean squares } \\
\cline { 3 - 6 } & & $g s$ & $A$ & $C i$ & $E$ & WUEi \\
\hline Salinity (S) & 4 & $0.0004^{*}$ & $7.891^{*}$ & $1564.500^{* *}$ & $0.691^{* *}$ & $5.102^{* *}$ \\
Linear regression & 1 & $0.0017^{* *}$ & $31.008^{* *}$ & $5548.800^{* *}$ & $2.640^{* *}$ & $18.620^{* *}$ \\
Quadratic regression & 1 & $0.00003^{\text {ns }}$ & $0.148^{\text {ns }}$ & $309.428^{\text {ns }}$ & $0.053^{\text {ns }}$ & $1.544^{\text {ns }}$ \\
N dose (ND) & 3 & $0.0002^{\text {ns }}$ & $1.533^{\text {ns }}$ & $51.927^{\text {ns }}$ & $0.102^{\text {ns }}$ & $1.041^{\text {ns }}$ \\
Linear regression & 1 & $0.0003^{\text {ns }}$ & $1.333^{\text {ns }}$ & $104.430^{\text {ns }}$ & $0.100^{\text {ns }}$ & $0.421^{\text {ns }}$ \\
Quadratic regression & 1 & $0.00008^{\text {ns }}$ & $0.266^{\text {ns }}$ & $43.350^{\text {ns }}$ & $0.020^{\text {ns }}$ & $0.041^{\text {ns }}$ \\
Interaction (SxND) & 12 & $0.0006^{\text {ns }}$ & $3.880^{\text {ns }}$ & $269.566^{\text {ns }}$ & $0.237^{\text {ns }}$ & $1.738^{\text {ns }}$ \\
Blocks & 2 & $0.0017^{* *}$ & $6.950^{\text {ns }}$ & $1792.916^{* *}$ & $0.100^{\text {ns }}$ & $0.202^{\text {ns }}$ \\
Residual & 38 & 0.0001 & 2.914 & 290.951 & 0.182 & 0.914 \\
CV (\%) & & 22.12 & 24.74 & 10.84 & 33.48 & 18.92 \\
\hline
\end{tabular}

** and * significant at 0.01 and 0.05 probability levels by F-test; ${ }^{\text {ns }}$ not significant by F-test.

A decreasing linear effect was observed on stomatal conductance $(g s)$ as a function of the increase in $\mathrm{ECw}$, with a relative reduction of $6.9 \%$ per unit increase in ECw, i.e., plants irrigated with $3.5 \mathrm{dS} \mathrm{m}^{-1}$ had a reduction in $g s$ of $22.7 \%$ (Figure 2A). Flexas et al. (2008), Silveira et al. (2016) and
Kusvuran (2012) claim that a high salinity level in the irrigation water has a harmful effect on stomatal opening, increasing the resistance to $\mathrm{CO}_{2}$ diffusion, a finding that was also observed in the present study, due to the conditions of saline stress to which guava plants were subjected in the evaluation period.

Figure 2. Stomatal conductance - $g s(\mathrm{~A}), \mathrm{CO}_{2}$ assimilation rate - $A(\mathrm{~B})$, internal $\mathrm{CO}_{2}$ concentration - $\mathrm{Ci}(\mathrm{C})$, transpiration - E (D) and instantaneous water use efficiency - WUEi (E) at 180 days after fruit pruning (DAFP) in the guava cv. 'Paluma' as a function of irrigation water salinity (ECw).
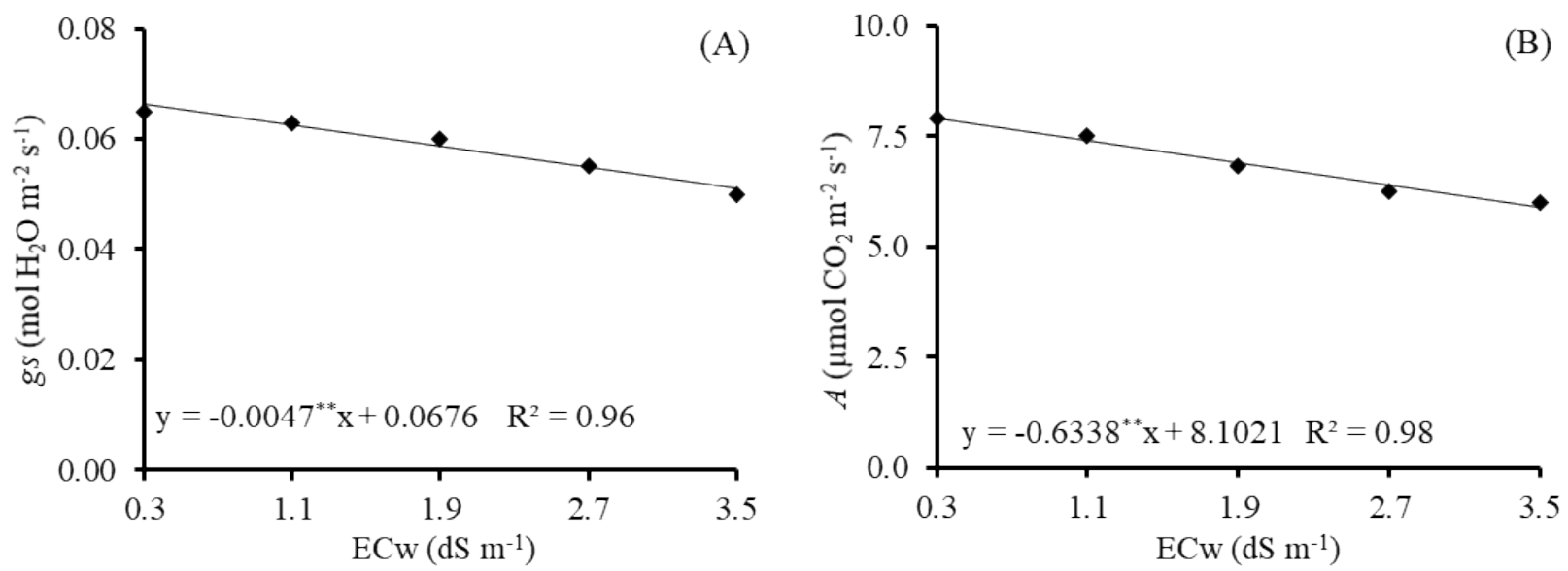

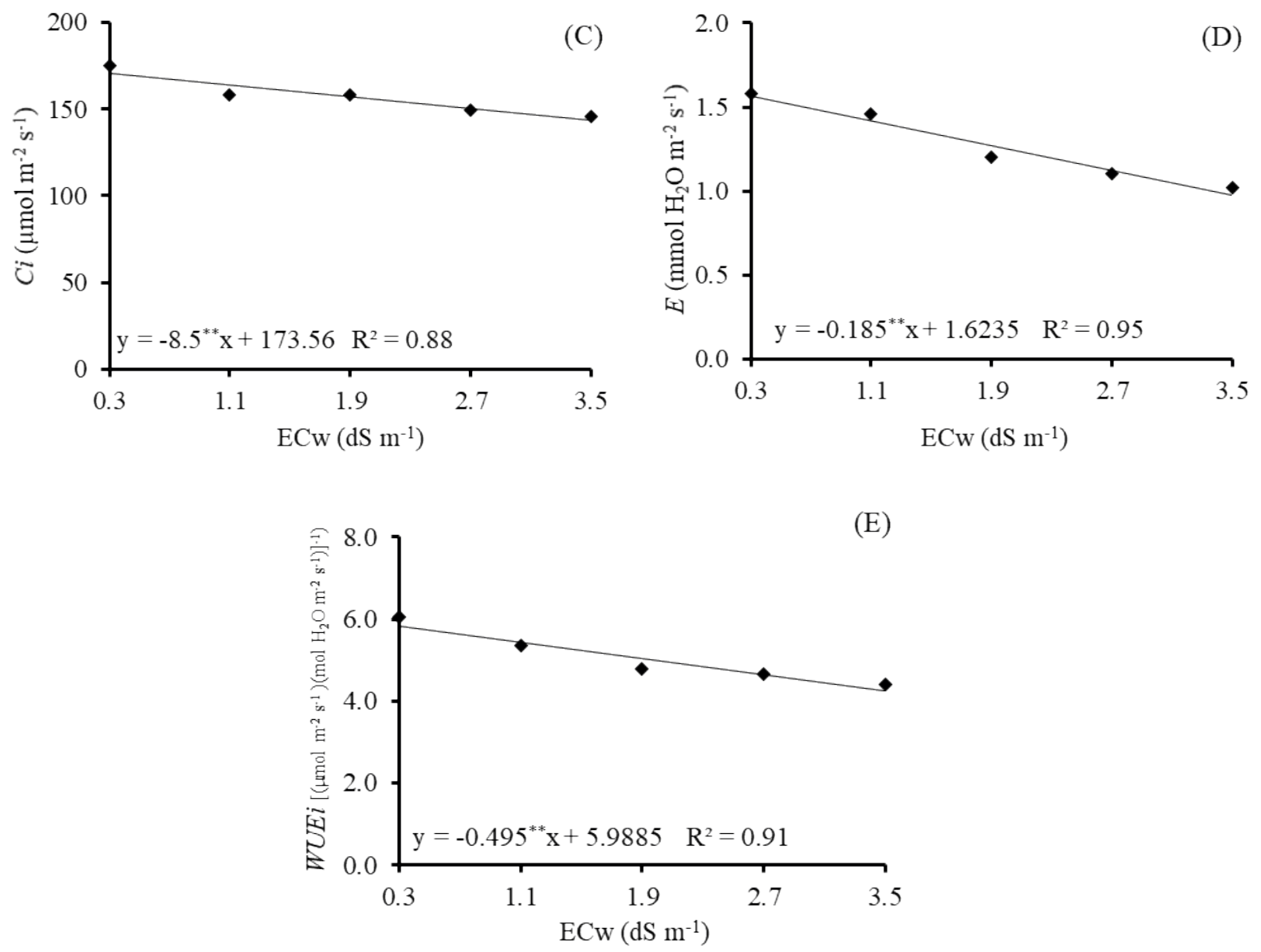

The $\mathrm{CO}_{2}$ assimilation rate, $A$ (Figure 2B), decreased from 7.9 to $5.9 \mu \mathrm{mol} \mathrm{m} \mathrm{m}^{-2} \mathrm{~s}^{-1}$ between the lowest $\left(0.3 \mathrm{dS} \mathrm{m}^{-1}\right)$ and highest salinity $\left(3.5 \mathrm{dS} \mathrm{m}^{-1}\right)$ treatments. This is equivalent to a reduction in $A$ of $25.63 \%$ or $7.82 \%$ per unit increase in ECw. Due to a reduction in $g s, A$ was negatively influenced. LópezCliment et al. (2008) reported that plants, when subjected to saline stress, tended to show reduced $\mathrm{CO}_{2}$ assimilation rates, caused by stomatal closure, which limits $\mathrm{CO}_{2}$ entry into the cells; therefore, it is the main cause of the reduction in photosynthesis (MUSYIMI; NETONDO; OUMA, 2007).

Figure $2 \mathrm{C}$ presents the values of internal $\mathrm{CO}_{2}$ concentration $(\mathrm{Ci})$, showing a linear reduction of $4.9 \%$ per unit increase in $\mathrm{ECw}$. This is a reduction in $C i$ of $15.9 \%$ in plants irrigated with $3.5 \mathrm{dS} \mathrm{m}^{-1}$ water compared with $0.3 \mathrm{dS} \mathrm{m}^{-1}$. Such a relative reduction in $C i$ can be attributed to the lower values of stomatal conductance, a common response of plants to saline stress (PRAXEDES et al., 2010; SILVA et al., 2011).

A decreasing linear effect occurred in transpiration rate $(E)$, which showed a relative reduction of $11.4 \%$ per unit increase in ECW (Figure 2D). This represents a reduction of $37.8 \%$ in plants subjected to ECW of $3.5 \mathrm{dS} \mathrm{m}^{-1}$ in comparison to 0.3 $\mathrm{dS} \mathrm{m}{ }^{-1}$ water. According to Gonçalves et al. (2010), there is a direct relationship between $E$ and $g s$, and the water vapor flux to the atmosphere decreases as the stomata close. Consequently, there is a reduction in transpiration and, as a result, a reduction in stomatal conductance. Similar results were reported by Sousa et al. (2016), who investigated irrigation water salinity levels of $0.6,1.2,1.8,2.4$ and $3.0 \mathrm{dS}$ 
$\mathrm{m}^{-1}$, and demonstrated that salinity of up to $3.0 \mathrm{dS} \mathrm{m}^{-1}$ leads to a significant reduction in the physiological variables, $g s, A$ and $E$, in orange plants.

Instantaneous water use efficiency (WUEi) was also linearly and negatively affected by irrigation water salinity at 180 DAFP, showing a reduction of about $8.3 \%$ per unit increase in ECw. Plants irrigated with water of the highest salinity $(3.5 \mathrm{dS}$ $\left.\mathrm{m}^{-1}\right)$ showed a reduction of $1.5\left[\left(\mu \mathrm{mol} \mathrm{m} \mathrm{m}^{-2} \mathrm{~s}^{-1}\right)(\mathrm{mol}\right.$ $\left.\left.\mathrm{H}_{2} \mathrm{O} \mathrm{m}^{-2} \mathrm{~s}^{-1}\right)^{-1}\right]$ in $W U E i$, in comparison to those subjected to an ECw of $0.3 \mathrm{dS} \mathrm{m}^{-1}$. Thus, it can be inferred that the increase in irrigation water salinity directly affects the WUEi of guava plants. These results may be associated with osmotic adjustment, i.e., the reduction in cell osmotic potential caused by the accumulation of organic solutes, contributing to the maintenance of water absorption and cell turgor and allowing for the continuity of physiological processes, such as stomatal opening, photosynthesis and cell expansion (SERRAJ; SINCLAIR, 2002).

Based on the F-test results (Table 3), the levels of irrigation water salinity had a significant $(\mathrm{p}<0.01)$ effect on the number of fruits (NF), mean fruit weight (MFW), fruit polar (FPD) and equatorial diameter (FED). However, the effect was not significant $(p<0.05)$ for the ratio between polar and equatorial diameters (FPD/FED). Nitrogen doses and the interaction between irrigation water salinity and $\mathrm{N}$ doses also caused no significant effect $(\mathrm{p}<0.05)$ on the variables studied.

The number of fruits in guava plants was negatively affected by the salt levels in the irrigation water and a linear equation was fitted (Figure 3A). There were reductions in NF of 1.2 fruits per unit increase in $\mathrm{ECw}$, leading to a decrease of $15.5 \%$ in plants subjected to ECW of $3.5 \mathrm{dS} \mathrm{m}^{-1}$ in comparison to those irrigated with $0.3 \mathrm{dS} \mathrm{m}^{-1}$ water. The reduction in the number of fruits per plant is probably due to the increase in salinity, resulting from the change in the osmotic potential, which reduces water consumption by plants and, consequently, the consumption of nutrients, and also reduces fruit setting.

Table 3. Summary of the analysis of variance for number of fruits (NF), mean fruit weight (MFW), fruit polar diameter (FPD), fruit equatorial diameter (FED) and ratio between polar and equatorial diameters (FPD/FED) in guava cv. 'Paluma' with saline water irrigation and different nitrogen doses in the first production cycle.

\begin{tabular}{|c|c|c|c|c|c|c|}
\hline \multirow{2}{*}{ Source of variation } & \multirow{2}{*}{$\mathrm{DF}$} & \multicolumn{5}{|c|}{ Mean squares } \\
\hline & & $\mathrm{NF}$ & MFW & FPD & FED & FPD/FED \\
\hline Salinity (S) 4 & & $29.333^{* *}$ & $1325.527^{* *}$ & $468.344^{* *}$ & $177.906^{* *}$ & $0.015^{\text {ns }}$ \\
\hline Linear regression & 1 & $112.133^{* *}$ & $4888.995^{* *}$ & $1814.296^{* *}$ & $630.208^{* *}$ & $0.026^{\mathrm{ns}}$ \\
\hline Quadratic regression & 1 & $0.595^{\mathrm{ns}}$ & $246.768^{\mathrm{ns}}$ & $3.543^{\mathrm{ns}}$ & $2.700^{\mathrm{ns}}$ & $0.009^{\mathrm{ns}}$ \\
\hline $\mathrm{N}$ dose (ND) & 3 & $35.600^{\mathrm{ns}}$ & $513.451^{\mathrm{ns}}$ & $23.865^{\mathrm{ns}}$ & $25.259^{\text {ns }}$ & $0.039^{\text {ns }}$ \\
\hline Linear regression & 1 & $28.213^{\mathrm{ns}}$ & $133.373^{\text {ns }}$ & $36.750^{\text {ns }}$ & $7.899^{\text {ns }}$ & $0.0002^{\mathrm{ns}}$ \\
\hline Quadratic regression & 1 & $64.066^{\mathrm{ns}}$ & $943.194^{\text {ns }}$ & $6.016^{\mathrm{ns}}$ & $67.628^{\text {ns }}$ & $0.1041^{\mathrm{ns}}$ \\
\hline Interaction (SxND) & 12 & $9.100^{\text {ns }}$ & $312.468^{\text {ns }}$ & $42.028^{\mathrm{ns}}$ & $9.885^{\text {ns }}$ & $0.032^{\mathrm{ns}}$ \\
\hline Blocks & 2 & $45.150^{* *}$ & $111.613^{\mathrm{ns}}$ & $17.715^{\mathrm{ns}}$ & $15.203^{\text {ns }}$ & $0.001^{\mathrm{ns}}$ \\
\hline Residual & 38 & 7.904 & 285.257 & 44.564 & 14.107 & 0.027 \\
\hline CV (\%) & & 12.22 & 29.67 & 11.26 & 8.45 & 12.30 \\
\hline
\end{tabular}

${ }^{* *}$ significant at 0.01 probability level by F-test; ${ }^{\text {ns }}$ not significant by F-test. 
Figure 3. Number of fruits - NF (A), mean fruit weight - MFW (B), fruit polar diameter - FPD (C) and fruit equatorial diameter - FED (D) at 180 days after fruit pruning (DAFP) in the guava cv. 'Paluma' cultivated under different levels of irrigation water electrical conductivity $(\mathrm{ECw})$ in the first production cycle.
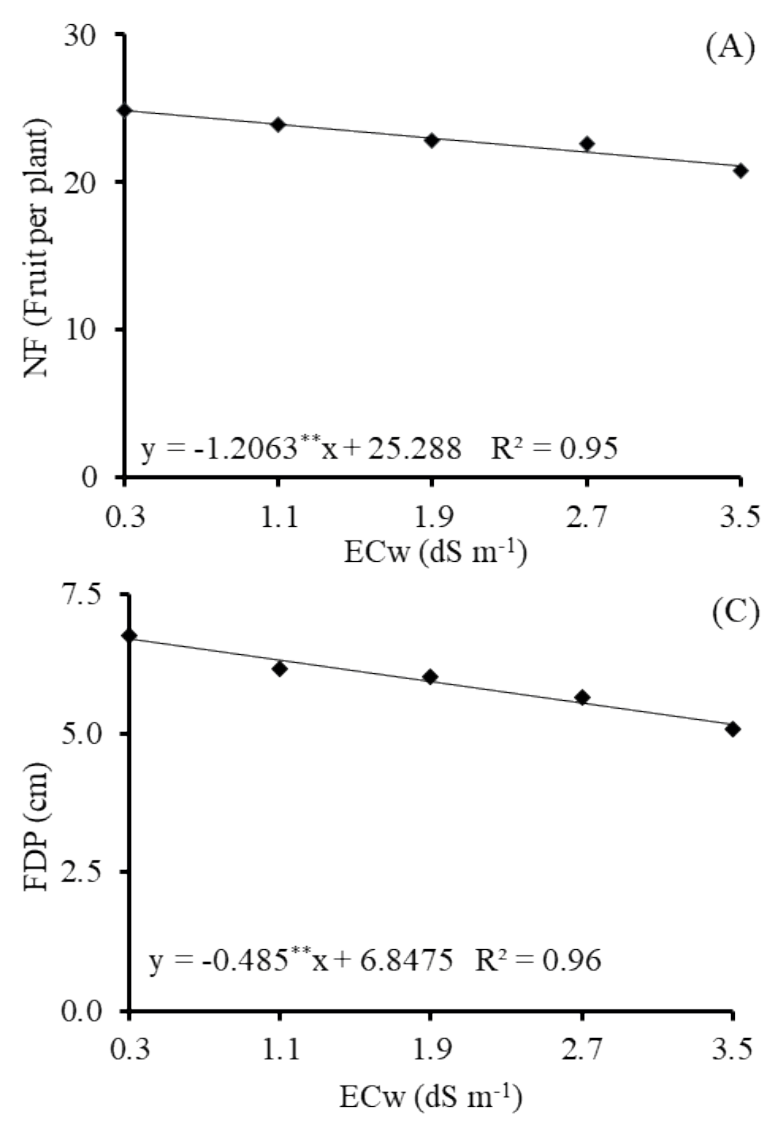

The increase in irrigation water salinity linearly inhibited mean fruit weight (MFW) at a rate of $8.0 \mathrm{~g}$ per unit increase in the electrical conductivity of the irrigation water (Figure 3B). The results decreased from 69.7 to $44.2 \mathrm{~g}$ fruit $^{-1}$ in plants subjected to $\mathrm{ECW}$ levels of 0.3 and $3.5 \mathrm{dS} \mathrm{m}^{-1}$, respectively, causing a loss of $36.6 \%$. Choudhry et al. (2001), studying the quality of guava fruits under field conditions and in a non-saline environment, claimed that fruits with a mean weight greater than $150 \mathrm{~g}$ are the most marketable. Thus, the fruits evaluated in the present study are below the comercial standard with respect to weight, and mean fruit weight suffered the most intense effect in comparison to the other production variables. Nonetheless, under the conditions of the present study, it can be claimed that water salinity negatively influenced the mean fruit weight in
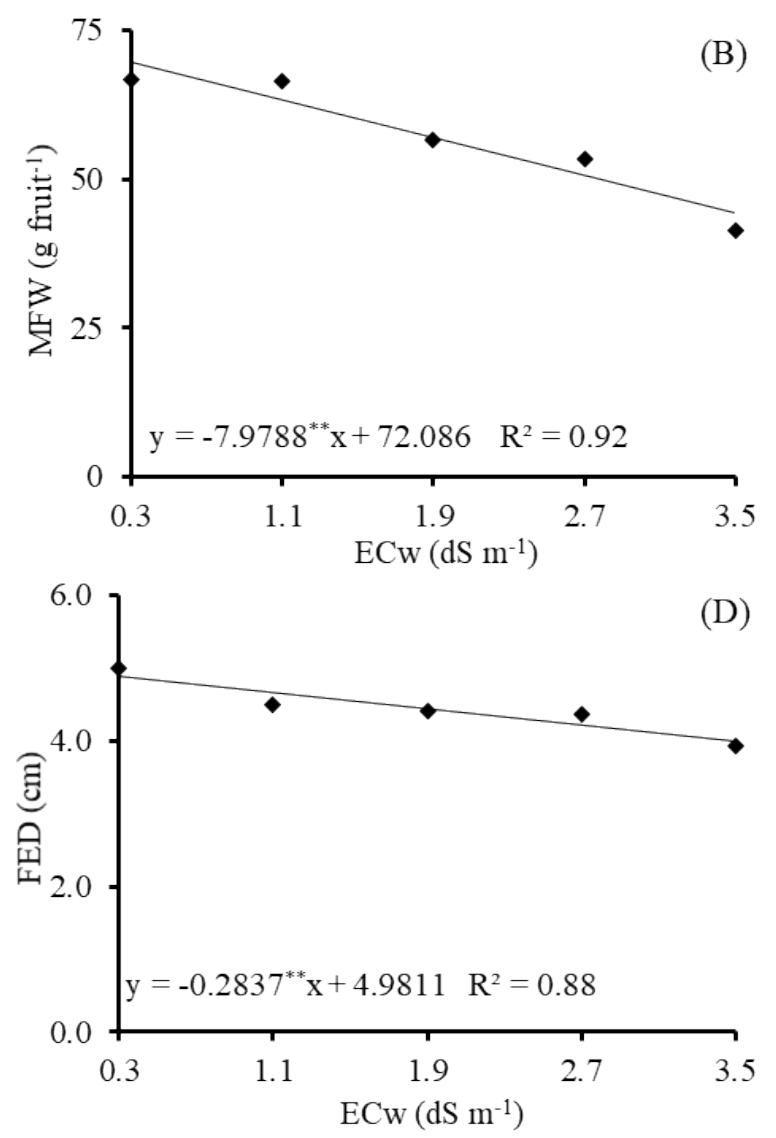

the guava crop, causing the values to fall below marketing standards.

Fruit polar diameter (FPD) was affected by irrigation water salinity and, according to the regression equation (Figure 3C), there were reductions in $\mathrm{FPD}$ of $7.1 \%$ per unit increase in ECw. The increase in ECw led to a reduction of $23.1 \%$ in the FPD of plants irrigated with $3.5 \mathrm{dS} \mathrm{m}^{-1}$ water, in comparison to plants grown under $\mathrm{ECw}$ of $0.3 \mathrm{dS} \mathrm{m}^{-1}$. Following the same trend observed for FPD, fruit equatorial diameter (FED) also fitted to a decreasing linear regression model (Figure 3D) and showed a relative reduction of $5.69 \%$ per unit increase in ECW. FED decreased by $18.5 \%$ between plants subjected to the highest $\left(3.5 \mathrm{dS} \mathrm{m}^{-1}\right)$ and lowest $\left(0.3 \mathrm{dS} \mathrm{m}^{-1}\right)$ salinity levels. 
As observed for number of fruits, polar diameter and equatorial diameter, the increment of salt concentration in the irrigation water caused a significant reduction in the mean weight of guava fruits (Figure 3B). Such a decrease is due to the effect of the saline stress, which may have caused reduction in the absorption of water and nutrients, and instability in the ionic balance and in plant metabolism, leading to losses in growth and production (MARSCHNER, 2005; MUNNS; TESTER, 2008; NIVAS et al., 2011). Reductions in fruit polar and equatorial diameters result from the decrease in stomatal conductance and leaf transpiration, which directly influences the absorption of water and nutrients by plants. In addition, the reduction observed in $\mathrm{CO}_{2}$ assimilation rate limited the production of photoassimilates and, consequently, caused reduction in the size of guava fruits. Taiz and Zeiger (2009) reinforce that gas exchange is of particular importance as it is the main source of organic carbon, energy for growth, biomass production and yield. Therefore, it is worth highlighting that the negative effects on gas exchange in the present study caused a reduction in the production variables.

In summary, management of $\mathrm{N}$ fertilizer application was not able to mitigate the effects of saline stress on the variables studied in this experiment. Perhaps the application of urea associated with an environment of high potential for volatilization (low relative air humidity and high temperatures) and/or leaching of the $\mathrm{N}$ applied inhibited its interaction with water salinity.

\section{Conclusions}

Irrigation water salinity above $0.3 \mathrm{dS} \mathrm{m} \mathrm{m}^{-1}$ negatively influences stomatal conductance, $\mathrm{CO}_{2}$ assimilation rate, internal $\mathrm{CO}_{2}$ concentration, transpiration rate, instantaneous water use efficiency, number of fruits, mean fruit weight, polar diameter and equatorial diameter of fruit.
Increments in $\mathrm{N}$ dose did not attenuate the deleterious effects of irrigation water salinity.

\section{Acknowledgments}

We thank the National Council for Scientific and Technological Development (CNPq) for funding the study, the Foundation of Support to the Development of Scientific and Technological Actions and Research of Rondônia (FAPERO) and the Coordination for the Improvement of Higher Education Personnel (CAPES) for the scholarship.

\section{References}

BARHOUMI, Z.; ATIA, A.; RABHI, M.; DJEBALL, W.; ABDELLY, C.; SMAOUI, A. Nitrogen and $\mathrm{NaCl}$ salinity effects on the growth and nutrient acquisition of the grasses Aeluropus littoralis, Catapodium rigidum, and Brachypodium distachyum. Journal of Plant Nutrition and Soil Science, Weinheim, v. 173, n. 1, p. 149-157, 2010.

BRITO, M. E. B.; SOARES, L. A. A. dos; FERNANDES, P. D.; LIMA, G. S. de; SÁ, F. V. da; MELO, A. S. de. Comportamento fisiológico de combinações copa/portaenxerto de citros sob estresse hídrico. Revista Brasileira de Ciências Agrárias, Recife, v. 7, p. 857-865, 2012. Suplemento.

CAVALCANTE, L. F.; CAVALCANTE, I. H. L.; PEREIRA, K. S. N.; OLIVEIRA, F. A.; GONDIM, S. C.; ARAÚJO, F. A. R. Germination and initial growth of guava plants irrigated with saline water. Revista Brasileira de Engenharia Agrícola e Ambiental, Campina Grande, v. 9, n. 4, p. 515-519, 2005.

CAVALCANTE, L. F.; SILVA, G. F.; GHEYI, H. R.; DIAS, T. J.; ALVES, J. C.; COSTA, A. P. M. Crescimento de mudas de maracujazeiro amarelo em solo salino com esterco bovino líquido fermentado. Revista Brasileira de Ciências Agrárias, Recife, v. 4, n. 4, p. 414-420, 2009.

CHAVES, M. M.; FLEXAS, J.; PINHEIRO, C. Photosynthesis under drought and salt stress: Regulation mechanisms from whole plant to cell. Annals of Botany, London, v. 103, n. 4, p. 551-560, 2009.

CHOUDHRY, M. M.; COSTA, T. S.; ARAÚJO, J. L. P. Goiaba: pós-colheita. In: CHOUDHRY, M. M. (Ed.). Agronegócio da goiaba. Brasília: EMBRAPA, 2001. p. 9-15. (Informação Tecnológica. Frutas do Brasil, 19). 
DIAS, M. J. T.; SOUZA, H. A.; NATALE, W.; MODESTO, V. C.; ROZANE, D. E. Adubação com nitrogênio e potássio em mudas de goiabeira em viveiro comercial. Semina: Ciências Agrárias, Londrina, v. 33, p. 2837-2848, 2012. Suplemento 1.

DIAS, T. J.; CAVALCANTE, L. F.; LEON, M. J.; FREIRE, J. L. O.; MESQUITA, F. O.; SANTOS, G. P.; ALBUQUERQUE, R. P. F. Produção do maracujazeiro e resistência mecânica do solo com biofertilizante sob irrigação com águas salinas. Revista Ciência Agronômica, Fortaleza, v. 42, n. 3, p. 644-651, 2011.

DONAGEMA, G. K.; CAMPOS, D. V. B. de; CALDERANO, S. B.; TEIXEIRA, W. G.; VIANA, J. H. M. (Org.). Manual de métodos de análise de solos. 2. ed. rev. Rio de Janeiro: Embrapa Solos, 2011. 230 p. (Embrapa Solos. Documentos, 132).

EMPRESA BRASILEIRA DE PESQUISA AGROPECUÁRIA - EMBRAPA. A cultura da goiaba. 2. ed. Brasília, Informação Tecnológica, 2010. 180 p.

. Sistema brasileiro de classificação de solos. 3. ed. Brasília, 2013. 353 p.

FERREIRA, D. F. Sisvar: um sistema computacional de análise estatística. Ciência e Agrotecnologia, Lavras, v. 35, n. 6, p. 1039-1042, 2011.

FLEXAS, J.; RIBAS, C. M.; DIAZ, E. A.; GALMÉS, J.; MEDRANO, H. Mesophyll conductance to $\mathrm{CO}_{2}$ : Current knowledge and future prospects. Plant, Cell and Environment, Oxford, v. 31, n. 5, p. 602-628, 2008.

FREIRE, J. L. O.; DIAS, T. J.; CAVALCANTE, L. F.; FERNANDES, P. D.; LIMA NETO, A. J. Rendimento quântico e trocas gasosas em maracujazeiro amarelo sob salinidade hídrica, biofertilização e cobertura morta. Revista Ciência Agronômica, Fortaleza, v. 45, n. 1, p. 1-10, 2014.

GONÇALVES, E. R.; FERREIRA, V. M.; SILVA, J. V.; ENDRES, L.; BARBOSA, T. P.; DUARTE, W. de. G. Trocas gasosas e fluorescência da clorofila a em variedades de cana-de-açúcar submetidas à deficiência hídrica. Revista Brasileira de Engenharia Agrícola e Ambiental, Campina Grande, v. 14, n. 4, p. 378-386, 2010.

INSTITUTO BRASILEIRO DE GEOGRAFIA E ESTATÍSTICA - IBGE. Produção agrícola municipal. Rio de Janeiro: IBGE, 2014. Disponível em: < https:// cidades.ibge.gov.br>. Acesso em: 11 jul. 2017.

INSTITUTO NACIONAL DE METEOROLOGIA INMET. Banco de dados meteorológicos para ensino e pesquisa. Patos: INMET, 2017. Disponível em: <http:// www.inmet.gov.br/portal/index.php? $\mathrm{r}=\mathrm{bdmep} / \mathrm{bdmep}>$. Acesso em: 09 jul. 2017.
KUSVURAN, S. Effects of drought and salt stresses on growth, stomatal conductance, leaf water and osmotic potentials of melon genotypes (Cucumis melo L.). African Journal Agricultural Research, Lagos, v. 7, n. 5, p. 775-781, 2012.

LACERDA, C. F.; CAMBRAIA, J.; OLIVA, M. A.; RUIZ, H. A. Osmotic adjustment in roots and leaves of two sorghum genotypes under $\mathrm{NaCl}$ stress. Brazilian Journal of Plant Physiology, Londrina, v. 15, n. 2, p. 113-118, 2003.

LÓPEZ-CLIMENT, M. F.; ARBONA, V.; PÉREZCLEMENTE, R. M.; GÓMEZ-CADENAS, A. Relationship between salt tolerance and photosynthetic machinery performance in citrus. Environmental and Experimental of Botany, Amsterdam, v. 62, n. 2, p. 176$184,2008$.

MACIEL, J. L.; DANTAS NETO, J.; FERNANDES, P. D. Resposta da goiabeira à lâmina de água e à adubação nitrogenada. Revista Brasileira de Engenharia Agrícola e Ambiental. Campina Grande, v. 11, n. 6, p. 571-577, 2007.

MANICA, I.; ICUMA, I. M.; JUNQUEIRA, N. T. V.; SALVADOR, J. O.; MOREIRA, A.; MALAVOLTA, E. Goiaba: do plantio ao consumidor: tecnologia de produção, pós-colheita, comercialização. Porto Alegre: Cinco Continentes, 2001. 124 p.

MARSCHNER, H. Mineral nutrition of higher plants. 2. ed. London: Academic Press, 2005. 889 p.

MUNNS, R.; TESTER, M. Mechanisms of salinity tolerance. Annual Review of Plant Biology, Palo Alto, v. 59, n. 1, p. 651-681, 2008.

MUSYIMI, D. M.; NETONDO, G. W.; OUMA, G. Effects of salinity on gas exchange and nutrient uptake in avocados. Journal of Biological Sciences, Toronto, v. 7, n. 3, p. 496-505, 2007.

NEVES, A. L. R.; LACERDA, C. F. de; GUIMARÃES, F. V. A.; GOMES FILHO, E.; FEITOSA, D. R. C. Trocas gasosas e teores de minerais no feijão-de-corda irrigado com água salina em diferentes estádios. Revista Brasileira de Engenharia Agrícola e Ambiental, Campina Grande, v. 13, p. $873-881,2009$. Suplemento.

NIVAS, D.; GAIKWAD, D. K.; CHAVN, P. D. Physiological responses of two morinda species under saline conditions. American Journal of Plant Physiology, New York, v. 6, n. 3 p. 157-166, 2011.

PEREIRA, F. M.; RYOSUKE, K. Contribuição da pesquisa científica brasileira no desenvolvimento de algumas frutíferas de clima subtropical. Revista Brasileira de Fruticultura. Jaboticabal, v. 33, n. 1, p. 92108, 2011. Edição Especial. 
PRAXEDES, S. C.; LACERDA, C. F. de; DAMATTA, F. M.; PRISCO, J. T.; GOMES-FILHO, E. Salt tolerance is associated with differences in ion accumulation, biomass allocation and photosynthesis in cowpea cultivars. Journal of Agronomy and Crop Science, Madison, v. 196, n. 3, p. 193-204, 2010.

RHOADES, J. D.; KANDIAH, A.; MASHALI, A. M. Uso de águas salinas para produção agrícola. Campina Grande: Estudos FAO. UFPB, 2000. 117 p. (Irrigação e Drenagem, 48).

SERRAJ, R.; SINCLAIR, T. R. Osmolyte accumulation: Can it really help increase crop yield under drought conditions? Plant Cell and Environent, Oxford, v. 25, n. 2, p. 333-341. 2002.

SILVA, E. M. Tolerância de porta-enxerto de goiabeira à salinidade da água de irrigação sob adubação nitrogenada. 2015. (Dissertação em Horticultura Tropical) - Universidade Federal de Campina Grande, Campina Grande.

SILVA, E.C.; NOGUEIRA, R. J. M. C.; ARAUJO, F. P.; MELO, N. F.; AZEVEDO NETO, A. D.; Physiological responses to salt stress in young umbu plants. Environmental and Experimental Botany, Barcelona, v. 63, n. 1-3, p. 147-157, 2008.

SILVA, F. L. B.; LACERDA, C. F.; SOUSA, G. G.; NEVES, A. L. R.; SILVA, G. L.; SOUSA, C. H. C. Interação entre salinidade e biofertilizante bovino na cultura do feijão-de-corda. Revista Brasileira de Engenharia Agrícola e Ambiental, Campina Grande, v. 15, n. 4, p. 383-389, 2011.

SILVEIRA, J. A. G.; SILVA, S. L. F.; SILVA, E. N.; VIÉGAS, R. A. Mecanismos biomoleculares envolvidos com a resistência ao estresse salino em plantas. In: GHEYI, H. R.; DIAS, N. S.; LACERDA, C. F.; GOMES FILHO, E. (Ed.). Manejo da salinidade na agricultura: Estudos básicos e aplicados. 2. ed. Fortaleza: INCTSal, 2016. v. 11, p. 181-196.

SOUSA, J. R. M. de; GHEYI, H. R.; BRITO, M. E. B.; XAVIER, D. A.; FURTADO, G. F. de. Trocas gasosas e produção de citros irrigados com águas salinas e adubação nitrogenada. Revista Caatinga, Mossoró, v. 29, n. 2, p. 415-424, 2016.

SOUZA, L. de P.; NOBRE, R. G.; SILVA, E. M. da; LIMA, G. S. de; PINHEIRO, F. W. A.; ALMEIDA, L. L. de S. Formation of 'Crioula' guava rootstock under saline water irrigation and nitrogen doses. Revista Brasileira de Engenharia Agrícola e Ambiental, Campina Grande, v. 20, n. 8, p. 739-745, 2016.

SOUZA, L. P.; NOBRE, R. G.; SILVA, E. M.; GHEYI, H. R.; SOARES, L. A. A. Produção de porta-enxerto de goiabeira cultivado com águas de diferentes salinidades e doses de nitrogênio. Revista Ciências Agronômica, Fortaleza, v. 48, n. 4, p. 596-604, 2017.

TAIZ. L.; ZEIGER E. Fisiologia vegetal. Porto Alegre: ARTMED, 2009. 729 p. 